\title{
Foraging density for squirrel monkey Saimiri sciureus in two forests in Puerto Lopez - Colombia
}

\author{
Densidad de forrajeo para el tití Saimiri sciureus en dos bosques \\ de Puerto López - Colombia
}

\author{
Jorge Astwood R, ${ }^{1}$ Biol, José Rodríguez P, ${ }^{2}$ M.Sc, Karen Rodríguez-C, ${ }^{3 *}$ M.Sc.
}

\begin{abstract}
${ }^{1}$ Universidad de los Llanos, Km 12 Via Puerto Lopez, Villavicencio-Meta, Colombia. ${ }^{2}$ Universidad de los Llanos, GIRGA research group, Km 12 Via Puerto Lopez, Villavicencio-Meta, Colombia. ${ }^{3}$ Universidade Federal de São Carlos, Laboratório de Biodiversidade Molecular e Conservação. R. Washington Luis, km 235 - SP-310 São Carlos - São Paulo - Brazil. Correspondence: karengiselle2004@gmail.com
\end{abstract}

Received: September 2013; Accepted: January 2014.

\begin{abstract}
Objective. Forest remnants were analyzed to determine the density of squirrel monkeys (Saimiri sciureus) and the degree of alteration of the forest, by selecting areas for the conservation and maintenance of the species in natural environments. Materials and methods. Linear transects were conducted on two wooden fragments, "La Reforma" and "Campo Hermoso" farms (Puerto Lopez, Meta, Colombia), recording sightings of squirrel monkeys and identifying the tree species used by the primates. Results. The fragments studied correspond to trails at the edge of water bodies with low connectivity. Highest density values were observed on the second transect of La Reforma, a possible consequence of an overcrowding phenomenon due to the high degree of isolation of the fragment. The species preferentially used as refuge and food source were: Bellucia grossularioides, Eugenia jambos, Inga alba, Mauritia flexuosa, Pseudolmedia laevis and Rollinia edulis. Conclusions. The phenology of the plant species allows for a dynamic food supply, considering the constant availability of food for the primates. Therefore, despite the evident ecological problem of these forests, it is possible to use active restoration programs to strengthen the existing dynamics and balance the biogeochemical dynamics of the ecosystem, so that socioeconomic human activities are not in conflict with conservation efforts and vice versa.
\end{abstract}

Key words: Food, conservation, population density, dispersion, refuges (Source: ASFA).

\section{RESUMEN}

Objetivo. Fueron analizados remanentes boscosos para determinar la densidad del Tití (Saimiri sciureus) y el grado de alteración del bosque, pretendiendo seleccionar áreas para conservación y mantenimiento de la especie en ambientes naturales. Materiales y métodos. Se realizaron transectos lineales en dos fragmentos boscosos, Hacienda La Reforma y Campo Hermoso (Puerto López, MetaColombia), registrando avistamientos del Tití e identificando las especies de árboles utilizadas por los primates. Resultados. Los fragmentos estudiados son senderos a la vera de cuerpos de agua con baja conectividad. Se observaron mayores valores de densidad en el segundo transecto de La 
Reforma; posiblemente como consecuencia de un fenómeno de sobrepoblación, debido al alto grado de aislamiento del fragmento. Las especies utilizadas preferencialmente como refugio y fuente alimenticia son: Bellucia grossularioides, Eugenia jambos, Inga alba, Mauritia flexuosa, Pseudolmedia laevis y Rollinia edulis. Conclusiones. La fenología de las especies de plantas permite un abastecimiento de alimento dinámico, considerando la disponibilidad constante de alimento para los primates, permitiendo afirmar que a pesar del evidente problema ecológico de estos bosques es posible utilizar programas de restauración activa para fortalecer la dinámica existente y equilibrar la dinámica biogeoquímica del ecosistema, para que las actividades antrópicas socio-económicas no estén en contraposición a la conservación y viceversa.

Palabras clave: Alimento, conservación, densidad poblacional, dispersión, refugios (Fuente: ASFA).

\section{INTRODUCTION}

The squirrel monkey (Saimiri sciureus, Cebidae) is a primate species with a wide distribution in Colombia. Reports for the region of Llanos Orientales indicate that they are located in the foothills of the East Andes, from 1500 m.a.s.l. to the Colombian Amazon forest and the banks of the Orinoco River (1).

Defler (1) has reported that the species occupies different types of forests, mainly gallery forests and even palm groves. Within these it frequently uses all arboreal strata for moving, foraging and refuge.

While the classification for the species by the IUCN (2) is of low risk and it is found in appendix II in the CITES, there is still a large concern in the department of Meta since this species has the highest rates of illegal capture within primates, from their natural sites to be sold as pets. Likewise, the threat of the implementation of agricultural crops, livestock activities, tourism development, human settlements and forest fragmentation has been noted (3).

In the year 19705,563 individuals were legally exported from Colombia to other sites of the world, illegal exports could double this number (4). Hence the need to study them in the field, in order to know their phylogeographic, ecological aspects and the composition of the habitat necessary for their survival (5).

Under these conditions, the research was developed in two forest remnants, La Reforma and Campo Hermoso farms in the vicinity of the municipality of Puerto Lopez (Meta, Colombia), I order to learn population-related aspects and the habitat of the squirrel monkey Saimiri sciureus, as a tool for the selection of areas for their conservation (Figure 1).

\section{INTRODUCCIÓN}

El mono Tití (Saimiri sciureus, Cebidae) es una especie de primate que presenta una amplia distribución en Colombia. Los reportes para la región de los Llanos Orientales indican que se encuentran en el piedemonte de la cordillera Oriental de los Andes, desde los 1500 m.s.n.m hasta la Amazonía colombiana y la margen del río Orinoco (1).

Defler (1) ha reportado que la especie ocupa diferentes tipos de bosques, principalmente bosques de galería e inclusive palmares. Dentro de estos usa frecuentemente todos los estratos arbóreos para su desplazamiento, forrajeo y refugio.

A pesar de que la clasificación para la especie en la IUCN (2) es de bajo riesgo y en el CITES se encuentra en el apéndice II, no deja de haber una preocupación grande en el departamento del Meta debido a que esta especie tiene las tasas más altas de extracción ilegal, dentro de los primates, desde sus sitios naturales con el fin de comercializarlos como mascotas. Igualmente se ha señalado como amenaza la implementación de cultivos agrícolas, actividades ganaderas, desarrollo turístico, asentamientos humanos y la fragmentación del bosque (3).

En el año de 1970 fueron exportados legalmente desde Colombia hacia otros sitios del mundo 5.563 individuos, las exportaciones ilegales podrían llegar a duplicar esta cantidad (4). Nace entonces la necesidad de estudiarlos en campo, con el fin de conocer aspectos filogeográficos, ecológicos y de la composición del hábitat necesaria para su sobrevivencia (5).

Bajo estas condiciones, la investigación fue desarrollada en dos remanentes de bosque, Hacienda La reforma y Campo hermoso, en inmediaciones del municipio de Puerto López (Meta, Colombia), para conocer aspectos poblacionales y del hábitat del tití Saimiri sciureus, como herramienta para la selección de áreas para su conservación (Figura 1). 


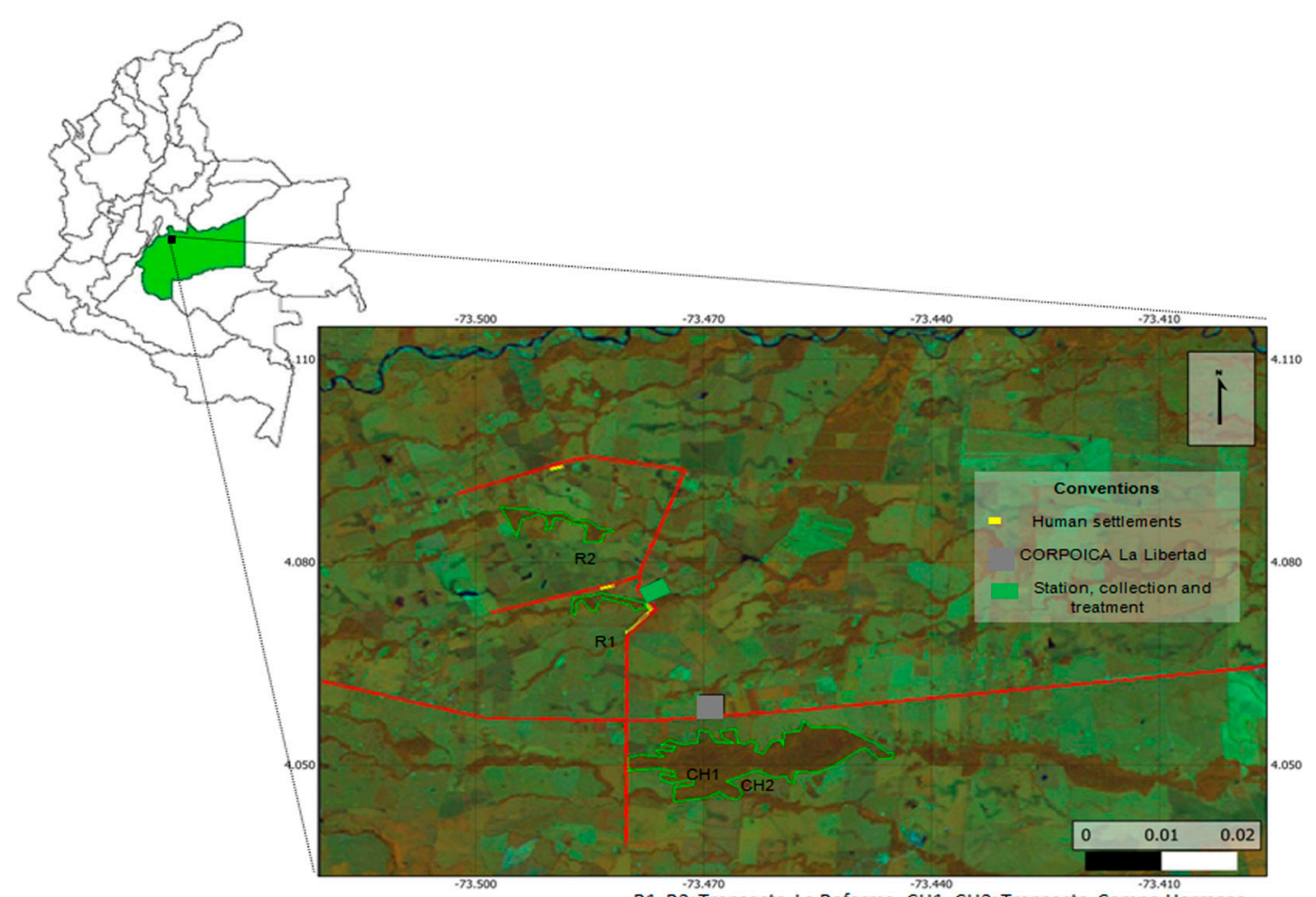

R1, R2: Transects; La Reforma. $\mathrm{CH} 1, \mathrm{CH} 2$ : Transects; Campo Hermoso.

Figure 1. Location of the study area in Colombia and transects analyzed in the region under study.

\section{MATERIALS AND METHODS}

Data collection. The density of the squirrel monkey in each forest was estimated using the method of linear transects of variable width (6). Two trenches were placed in each of the forest, La Reforma and Campo Hermoso, separated by a minimum of $500 \mathrm{~m}$ (Table 1 ).

The access roads, human settlements and soil uses were identified in each forest (Figure 1). A sampling point was established in each observation, which was demarcated during the walks for the estimation of density.

Table 1. Location and length of the transects established in two forest remnants: La Reforma and Campo Hermoso.

\begin{tabular}{|c|c|c|c|c|}
\hline Area & $\mathbf{T}$ & $\begin{array}{c}\text { Length } \\
(\mathbf{K m})\end{array}$ & $\begin{array}{c}\text { Start } \\
\text { Coordinate }\end{array}$ & End Coordinate \\
\hline \multirow{4}{*}{ La Reforma (Ref) } & \multirow{2}{*}{1} & \multirow{2}{*}{0.85} & N 404'25,7" & N 404'21,6" \\
\hline & & & W $73^{\circ} 28^{\prime} 55^{\prime \prime}$ & W $73^{\circ} 28^{\prime} 30.5^{\prime \prime}$ \\
\hline & \multirow{2}{*}{2} & \multirow{2}{*}{0.9} & N 40 $5^{\prime} 10.6^{\prime \prime}$ & N 405'3.6" \\
\hline & & & W 73029'18.7" & W 73029'46.9" \\
\hline \multirow{4}{*}{$\begin{array}{l}\text { Campo Hermoso } \\
\text { (CH) }\end{array}$} & \multirow{2}{*}{1} & \multirow{2}{*}{1} & N 403'6.12" & N 403'7.6" \\
\hline & & & W $73^{\circ} 28^{\prime} 27.2^{\prime \prime}$ & W $73^{\circ} 28^{\prime} 54.8^{\prime \prime}$ \\
\hline & \multirow{2}{*}{2} & \multirow{2}{*}{1} & N 4ㅇ'56. $8^{\prime \prime}$ & N 402'58.37" \\
\hline & & & W $73^{\circ} 28^{\prime} 21.41^{\prime \prime}$ & W 73027'49" \\
\hline
\end{tabular}

T=Transects

\section{MATERIALES Y METODOS}

Recolección de datos. La densidad del tití en cada bosque fue estimada con el método de transectos lineales de ancho variable (6). En cada uno de los bosques, La reforma y Campo hermoso, se establecieron dos trochas, separadas entre ellas por un mínimo de 500m (Tabla 1).

Se identificaron en cada bosque, vías de acceso, asentamientos humanos y usos del suelo (Figura 1). Se procedió a establecer en cada observación un punto de muestreo, el cual fue demarcado durante los recorridos para la estimación de la densidad.

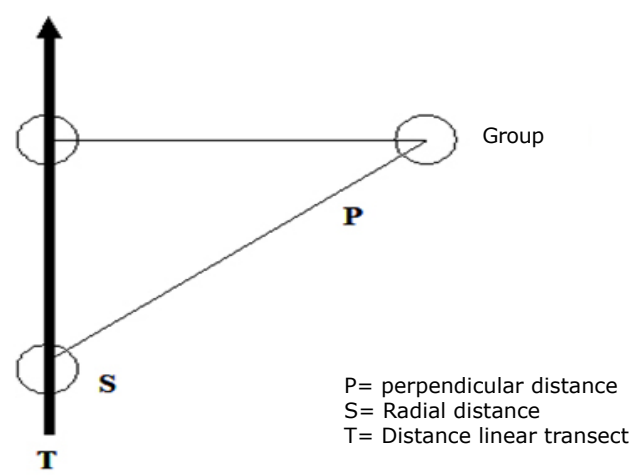

Figure 2. Variables measured during observation walks of Saimiri sciureus. 
The journeys to the samplings sites were carried out three days a week, twice a day, at 0500 $\mathrm{HR}$ and at $1000 \mathrm{HR}$ and between $1400 \mathrm{HR}$ and $1600 \mathrm{HR}$, since the activity peaks of the squirrel monkey occur at these hours (3.7). The walks were made at an average speed of $0.5 \mathrm{~km} /$ hour.

The following information was recorded on each journey: perpendicular distance $(P)$ : animal detected to the transect line; radial distance (S): distance of the observer when detecting the animal (Figure 2); time of detection; distance in the transect; number of individuals and number of troops.

Statistical analysis. The size and shape of the patches, degree of isolation, scattering, interaction and heterogeneity were evaluated through digital cartographic analysis of the vegetation cover map of the IGAC (8) and Landsat images (Figure 1) in order to estimate the degree of alteration in each forest.

Each of the above named features were calculated through indexes: shape index $(D i)$ that connects the size and shape of patches; isolation index of a patch (ri) which connects the distance between patches; isolation index of all patches (ai) which shows the degree of isolation of all patches and also the interaction index between patches $(I i)$, all such calculated according to the formulas proposed by Gonzalez et al (9).

Identification of flora. The tree species used by primates and the plant composition they were feeding from (fruit, young leaves or flowers) were marked and identified using the methodology employed by Dueser and Shugart Jr (10), the species preferentially used as refuge were also identified. The height in the tree or shrub at which the animals were found and the activity carried out at the time of the observation (11) were noted in each sighting. Some trees that provided food were marked to perform phonological follow-up.

\section{RESULTS}

The forest fragments studied were limited to small trails on the edge of water bodies that, in most cases, were not even within the provisions of the Law in terms of conservation and maintenance of vegetation around streams as provided for by Decree $877 / 1976$ issued by the Ministry of Agriculture of Colombia. The patches showed irregular shapes mainly due to the high intervention to which they are subjected in addition to the low connectivity between the same (Figure 1). In the vicinity of these forests, the land is mainly used for cattle ranching and the cultivation of African palm. In addition, in the
Los recorridos para los muestreos se realizaron tres días a la semana, dos veces por día, de las 0500 HR a las 1000 HR y entre las 1400 HR y 1600 HR, debido a que en estas horas se registran los picos de mayor actividad del tití $(3,7)$. Los recorridos fueron realizados a una velocidad media de $0.5 \mathrm{~km} /$ hora.

En cada recorrido, se registró la siguiente información: distancia perpendicular $(P)$ : animal detectado hasta la línea del transecto; distancia radial (S): distancia del observador al momento de ser detectado el animal (Figura 2); hora de detección; distancia en el transecto; número de individuos y número de tropas.

Análisis estadístico. Para estimar el grado de alteración en cada bosque fueron evaluados tamaño y forma de los parches, grado de aislamiento, dispersión, interacción y heterogeneidad a través del análisis cartográfico digital del mapa de coberturas vegetales del IGAC (8) e imágenes Landsat (Figura 1).

Cada una de las características anteriormente nombradas fueron calculadas a través de índices: índice de forma (Di) que relaciona el tamaño y la forma de los parches; índice de aislamiento de un parche (ri) el cual relaciona la distancia entre los parches; índice de aislamiento de todos los parches (ai) que muestra el grado de aislamiento de todos los parches e igualmente el índice de interacción entre parches (Ii), todos ellos calculados siguiendo las formulas propuestas por González et al (9).

Identificación de la flora. Utilizando la metodología empleada por Dueser y Shugart Jr (10) se marcaron e identificaron las especies de los árboles que eran utilizados por los primates como alimento y cuál era la composición vegetal de la cual se estaban alimentando (frutos, hojas jóvenes o flores), igualmente se identificaron las especies usadas preferencialmente como refugio. En cada avistamiento se anotaron, la altura en el árbol o arbusto en la cual se encontraron los animales y la actividad realizada al momento de la observación (11). Algunos árboles que suministraban alimento fueron marcados para realizar un seguimiento fenológico.

\section{RESULTADOS}

Los fragmentos de bosque estudiados se limitaron a pequeños senderos a la vera de los cuerpos de agua que en la mayoría de ocasiones ni siquiera se encontraban dentro de las disposiciones de Ley en términos de conservación y mantenimiento de la vegetación en rondas de caños tal como lo prevé el Decreto 877 de 1976 del Ministerio de Agricultura de Colombia. Los parches presentaron formas irregulares principalmente por la alta 
proximity to the forest of La Reforma there is an hydrocarbon processing plant.

The results for the rate of encounters (ER), estimated density of the troops (DS) and density of animals per hectare in each sampling area (D) are listed in figure 3. The highest values for the three variables were observed in transect number two of La Reforma. However, it is possible that there is some overpopulation phenomenon occurring there.

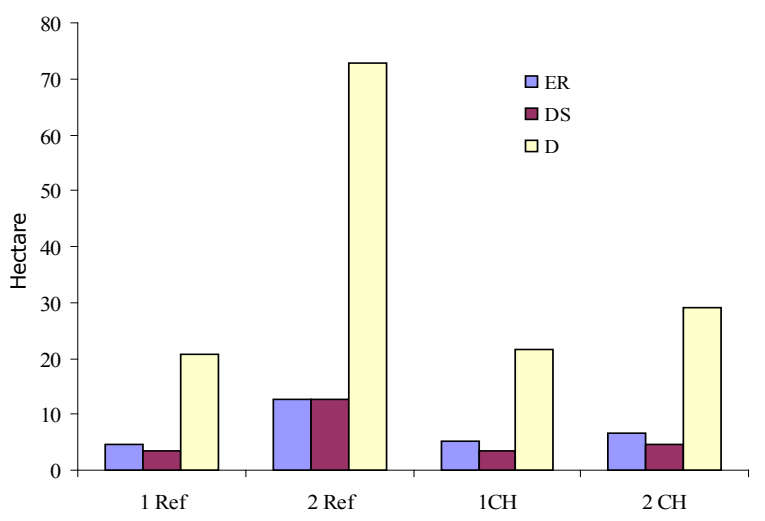

Figure 3. Densities calculated for populations of Saimiri sciureus in the transects made.

When analyzing the rates of encounter of troops or groups calculated for each area, a tendency to increase in proportion to the perpendicular distance in meters was observed.

Within the alteration indices of forest fragments, the shape index $(D i)$ showed that the fragments analyzed had an irregular shape and were far from Euclidean parameters (Table 2). In terms of the isolation between patches $(r i)$, it was observed that the fragment where transect 1 of La Reforma is located showed the greatest separation with neighboring patches (Figure 4).

However, the isolation index of all patches (ai) showed that the area with the greatest isolation with all patches within the landscape is the fragment where transect 2 of La Reforma is located. Finally, the index of interaction between patches (Ii) allowed detecting that the fragment

Table 2. Degree of landscape alteration through the analysis of satellite images.

\begin{tabular}{cccccc}
\hline \multicolumn{1}{c}{ Area } & Transect & $\boldsymbol{D i}$ & $\boldsymbol{r i}$ & $\boldsymbol{a i}$ & $\boldsymbol{I i}$ \\
\hline \multirow{2}{*}{ La Reforma } & 1 & 2.33 & 0.0006 & 542.6 & 1.76 \\
& 2 & 2.66 & 0.0002 & 1049.6 & 2.06 \\
Campo Hermoso & 1 y 2 & 2.57 & 0.0003 & 996.2 & 25.84 \\
\hline
\end{tabular}

intervención a la cual estos se ven sometidos, además, de la baja conectividad entre ellos (Figura 1). En inmediaciones de estos bosques, la tierra es usada principalmente para ganadería extensiva y cultivo de palma africana. Además, en cercanías al bosque de La reforma existe una central de manejo de hidrocarburos.

Los resultados para la tasa de encuentros (ER), densidad estimada de las tropas (DS) y densidad de animales por hectárea en cada zona de muestreo (D) se encuentran relacionados en la figura 3. En el transecto número dos de La Reforma, se observaron los mayores valores para las tres variables. Sin embargo, es posible que allí se esté presentando algún fenómeno de sobrepoblación.

Al analizar las tasas de encuentro de tropas o grupos calculados para cada zona, se evidenció una tendencia a aumentar de manera proporcional a la distancia perpendicular en metros.

Dentro de los índices de alteración de los fragmentos de bosque, el índice de forma $(D i)$, expresó que los fragmentos analizados presentaron una forma irregular y se alejaron de cualquiera de los parámetros euclidianos (Tabla 2). En cuanto al aislamiento entre los parches (ri), se observó que el fragmento donde se encuentra ubicado el transecto 1 de La Reforma, es el que presentó mayor separación con los parches vecinos (Figura 4).

Sin embargo, el índice de aislamiento de todos los parches (ai), mostró que la zona con mayor aislamiento con todos los parches dentro del paisaje, es el fragmento donde se encuentra ubicado el transecto 2 de La Reforma. Finalmente, el índice de interacción entre parches $(I i)$, permitió detectar que el fragmento de Campo Hermoso, presentó un mayor grado de interacción con sus parches vecinos al compararlo con los otros fragmentos analizados.

Durante los recorridos de los transectos se encontró que las especies utilizadas preferencialmente como refugio y como fuente alimenticia: Bellucia grossularioides, Eugenia jambos, Inga alba, Mauritia flexuosa, Pseudolmedia laevis y Rollinia edulis (Tabla 3).

Es importante destacar que durante el transcurrir del tiempo, la mayoría de especies van cambiando su estado fenológico de manera asincrónica, por tal razón, el abastecimiento de alimento para los primates es dinámico en términos de la parte de la planta disponible en una época determinada (Flor, fruto, hoja), pero constante en el sentido de que los animales siempre cuentan con algún recurso para su alimentación, que es además, relativamente abundante. 


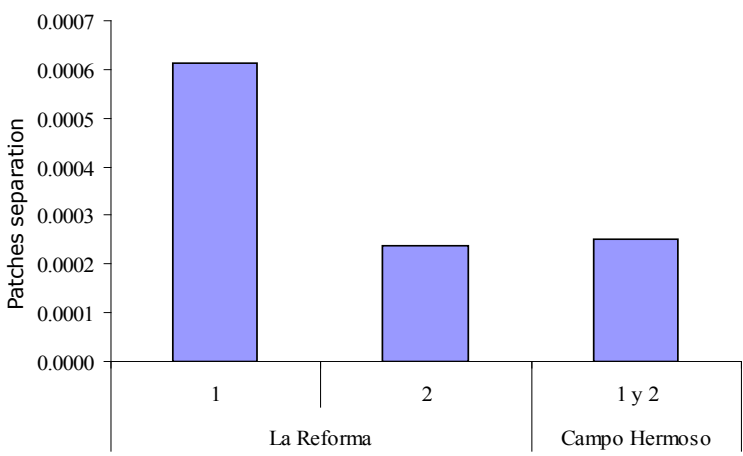

Figure 4. Patch isolation index (ri).

of Campo Hermoso had the greatest degree of interaction with its neighboring patches when compared with other fragments analyzed.

During the walks of the transects it was found that the species preferentially used as refuge and as food source were: Bellucia grossularioides, Eugenia jambos, Inga alba, Mauritia flexuosa, Pseudolmedia laevis and Rollinia edulis (Table 3).

It is worth noting that during the passing of time, most species are changing their phenological condition asynchronously, for this reason, the supply of food for primates is dynamic in terms of the part of the plant available at a given time (flower, fruit, leaf), but constant in the sense that animals always have some resource for feeding, which is also relatively abundant.

\section{DISCUSSION}

Due to the low degree of conservation of the fragments, transects were established within vegetation strips round a body of water. Despite the fact that Buckland et al (6) recommend that transects are established perpendicularly to avoid having a bias toward the greater abundance of resources in said strips, it was not performed in this way because transects are located in open areas of grasslands where it is not possible to collect data related to the density of primates. Similarly, the area was not enough to locate the five trenches proposed, separated at least by 500 meters.

With regard to the conditions of conservation of the forests, the establishment of cattle farms in the area of La Reforma typifies the area as of high intervention with forest presence between $11-20 \%$ of the landscape and in the area of the farm Campo Hermoso, and as of low intervention with forest presence of 31$40 \%$. Such information is consistent with what was observed in the results obtained during
Table 3. Number of trees used as food sources and/ or refuge in the fragments analyzed.

\begin{tabular}{|c|c|c|c|}
\hline Transect & Species & $\begin{array}{c}\begin{array}{c}\text { Foraging \# } \\
\text { Trees }\end{array} \\
\end{array}$ & $\begin{array}{c}\text { Refuge \# } \\
\text { Trees }\end{array}$ \\
\hline \multirow[t]{7}{*}{ Ref 1} & Bellucia grossularioides & 5 & 4 \\
\hline & Eugenia jambos & 5 & 0 \\
\hline & Guatteria recurvisepala & 5 & 0 \\
\hline & Inga alba & 5 & 2 \\
\hline & Mauritia flexuosa & 2 & 4 \\
\hline & Pseudolmedia laevis & 5 & 0 \\
\hline & Rollinia edulis & 4 & 2 \\
\hline \multirow[t]{8}{*}{ Ref 2} & Alchornea triplinervia & 0 & 3 \\
\hline & Bellucia grossularioides & 3 & 0 \\
\hline & Eugenia jambos & 3 & 0 \\
\hline & Inga alba & 3 & 2 \\
\hline & Inga edulis & 4 & 0 \\
\hline & Mauritia flexuosa & 3 & 3 \\
\hline & Pseudolmedia laevis & 1 & 3 \\
\hline & Virola sebifera & 0 & 2 \\
\hline \multirow[t]{8}{*}{$\mathrm{CH} 1$} & Alchornea triplinervia & 0 & 4 \\
\hline & Bellucia grossularioides & 5 & 3 \\
\hline & Casearia javitensis & 2 & 0 \\
\hline & Eugenia jambos & 5 & 3 \\
\hline & Guatteria recurvisepala & 2 & 2 \\
\hline & Inga alba & 5 & 0 \\
\hline & Mauritia flexuosa & 4 & 3 \\
\hline & Pseudolmedia laevis & 3 & 3 \\
\hline \multirow[t]{8}{*}{$\mathrm{CH} 2$} & Bellucia grossularioides & 4 & 0 \\
\hline & Inga alba & 3 & 1 \\
\hline & Inga edulis & 5 & 0 \\
\hline & Mauritia flexuosa & 2 & 3 \\
\hline & Pseudolmedia laevis & 2 & 2 \\
\hline & Virola sebifera & 0 & 5 \\
\hline & Xylopia aromatica & 3 & 0 \\
\hline & Zygia basijuga & 3 & 0 \\
\hline
\end{tabular}

Ref: Reforma; $\mathrm{CH}$ : Campo Hermoso

\section{DISCUSIÓN}

Debido al bajo grado de conservación de los fragmentos, se establecieron transectos dentro de las franjas de vegetación de ronda de un cuerpo de agua. A pesar que Buckland et al (6) recomiendan que los transectos se establezcan de manera perpendicular para evitar el sesgo de mayor abundancia de recursos en dichas franjas, no fue realizado de esta manera, porque los transectos habrían quedado ubicados en las áreas abiertas de pastizales donde no es posible recolectar datos de densidad de primates. Igualmente el área no fue suficiente para ubicar las cinco trochas propuestas, separadas al menos por 500 metros.

Con respecto a las condiciones de conservación de los bosques, el establecimiento de ganaderías en la zona de La Reforma tipifican el área con alta intervención con una presencia del bosque entre $11-20 \%$ del paisaje y en la zona de la hacienda Campo Hermoso, una baja intervención con una presencia entre el $31-40 \%$ de bosque. Tal información es consecuente con lo observado en los resultados obtenidos durante el presente estudio, 
this study, being directly related to the density values obtained (Figure 3 ). Thus, the density of specimens per hectare in two transects of Campo Hermoso (21.6 and 29 animals/Ha) is more in line with the amounts of the available habitats than in the area of La Reforma (20.6 and 72.7 animals/Ha) if taking into account that the area of the latter is substantially smaller.

If strictly observing the numbers of the rates of encounters and density in the area of La Reforma, especially in the transect 2 , it may be possible to think that by having a density close to and/or above that of Campo Hermoso, the condition of the populations is more favorable; however, the high values for the shape index $(D i)$, the isolation index with respect to a patch and all patches (ai) and the interaction index (Ii) (Table 2), allow observing the little connectivity of vegetation fragments in La Reforma and therefore argue that rather than a higher density of individuals per area unit, what is observed is a clear process of overcrowding due to the high reproduction capacity of Saimiri sciureus $(12,13)$. As the gaps of small forests grow larger, there is an increase in the rates of extinction and a decrease in the recolonization by fragmentation of the habitat (14). Even under unfavorable conditions; this is a phenomenon that could trigger, in the short term, health problems within the population, with a potential risk for human beings in terms of public health

The troops of primates registered in transect 2 of La Reforma showed a higher average in the perpendicular distance of troop detection, this phenomenon may be related to increased competition for resources (12) and possible stress levels that this produces on animals, which are more cautious when there are humans walking through the forest floor, therefore they keep themselves farther away.

In terms of availability of resources, in the area of La Reforma, 10 tree species were recorded, belonging to eight families divided in the two transects. Likewise, there were 12 species in the area of Campo Hermoso belonging to 9 families. Defler (1) and Williams et al (12), reported that Saimiri sciureus exploits the food resources of the families Moraceae, Fabaceae, Flacourtiaceae, Melastomataceae, Annonaceae and Myrtaceae, among others, these observations are consistent with those made in this study, in which it was observed that species of the genera Bellucia (Melastomataceae), Eugenia (Myrtaceae), Guateria (Annonaceae), Inga (Fabaceae), Mauritia (Arecaceae), Pseudolmedia (Moraceae), Rollinia (Annonaceae), Alchornea (Euphorbiaceae), Virola (Myristicaceae), Casearia relacionándose directamente con los valores de densidad obtenidos (Figura 3). Así, la densidad de individuos por hectárea en los dos transectos de Campo Hermoso (21.6 y 29 animales/ha), está más acorde con las cantidades del hábitats disponibles que en la zona de La Reforma (20.6 y 72.7 animales/ha) si se tiene en cuenta que el área de ésta última es sustancialmente menor.

Si se observan estrictamente los números de tasas de encuentro y densidad en el área de La Reforma, especialmente del transecto 2, podría pensarse que por presentar una densidad cercana y/o superior a la de Campo Hermoso, la condición de las poblaciones es más favorable; sin embargo, los altos valores para los índices de forma $(D i)$, el índice de aislamiento con respecto a un parche y todos los parches (ai) y el índice de la interacción (Ii) (Tabla 2), permiten observar la escasa conectividad de los fragmentos de vegetación en La Reforma y por tanto argumentar que más que una mayor densidad de individuos por unidad de área, lo que se observa es un claro proceso de hacinamiento debido a la alta capacidad de reproducción de Saimiri sciureus $(12,13)$. A medida que se hacen mayores las separaciones de los pequeños bosques hay incremento en las tasas de extinción y una disminución de la recolonización por fragmentación del hábitat (14). Inclusive bajo condiciones desfavorables; fenómeno que podría desencadenar, a corto plazo, problemas de salud dentro de la población, con el potencial riesgo que tiene para el ser humano en términos de salud pública.

Las tropas de primates registradas en el transecto 2 de La Reforma, presentaron un promedio más alto en la distancia perpendicular de detección de tropas, este fenómeno puede estar relacionado con una mayor competencia por recursos (12) y los posibles niveles de estrés que esto produce en los animales, los cuales son más cautelosos cuando algún ser humano camina por el suelo del bosque, por ello se mantienen más alejados.

En cuanto a disponibilidad de recursos, en el área de La Reforma, se registraron 10 especies de árboles, pertenecientes a ocho familias repartidas en los dos transectos. Asimismo, en el área de Campo Hermoso, se registraron 12 especies, pertenecientes a 9 familias. Defler (1) y Williams et al (12), reportan que Saimiri sciureus, explota recursos alimenticios de las familias Moraceae, Fabaceae, Flacourtiaceae, Melastomataceae, Annonaceae y Myrtaceae, entre otras, dichas observaciones están acordes con las presentes en este estudio, en las que se observó que especies de los géneros Bellucia (Melastomataceae), Eugenia (Myrtaceae), Guateria (Annonaceae), Inga (Fabaceae), Mauritia (Arecaceae), Pseudolmedia (Moraceae), Rollinia (Annonaceae), Alchornea 
(Flacourtiaceae), Xylopia (Annonaceae) and Zygia (Fabaceae), alternate their phenological stages, allowing the primate troops to enjoy a variety of food resources over time in Gallery forests with a lot of obstacles to predators and a adequate supply of insects, bats and lizards (15), as it occurs in agricultural landscapes (Table 3).

Coupled to this and although the graphics show, at first glance, some differences in the availability of food resources and shelter, no significant differences were found $(p>0.05)$ in the means of any of the variables. This means that S. sciuerus uses all resources available on an equitable basis and for the results of this study there is no trend or marked preference towards any of them, neither for food nor shelter.

The relationship between abundance, frequency, dominance and basal area is proportional, which indicates that all species have a significant degree of importance to the structure of the patches and each species is therefore fundamental for the maintenance of the populations of $S$. sciureus.

The disappearance or isolation of primates entails important consequences since in their trophic niche they are important dispersers of seeds and modify the composition and distribution of forests. In addition, they have a very important role as insect controllers (3).

The serious transformation and fragmentation processes to which the forests and ecosystems of the area have been subject to were evident during the development of this study. This aspect is a neuralgic point and must be the epicenter of the conservation efforts, i.e. the permanence and health of the species' population, not only of primates, but the rest of the fauna and flora inhabiting these forests, depends mainly on the implementation of strategies for the restoration of connectivity and the reestablishment of biological corridors that allow the networks for the transfer of energy and biomass of the system to work properly.

The size of squirrel monkey troops is positively associated with the percentage of the tree component, fruit supply, wet areas and the density of the edges in the ecotone and negatively with the presence of other primates, predators or the absence of insects (3). By preferring the secondary habitat, the mix of forests in different succession stages increases the vulnerability of the species by the presence of man and the indiscriminate use of agrochemicals.
(Euphorbiaceae), Virola (Myristicaceae), Casearia (Flacourtiaceae), Xylopia (Annonaceae), y Zygia (Fabaceae), alternan sus estados fenológicos, permitiendo que las tropas de primates cuenten con variedad de recursos alimenticios a los largo del tiempo, en bosques de galería con gran cantidad de obstáculos a predadores y buena oferta en insectos, murciélagos y lagartijas (15), como ocurre en agropaisajes (Tabla 3).

Sumado a esto, y aunque en los gráficos citados se encuentren, a primera vista, algunas diferencias en cuanto a la disponibilidad de recursos de alimento y refugio, no se encontraron diferencias significativas ( $p>0.05$ ), en las medias de alguna de las variables. Quiere decir esto, que $S$. sciuerus, utiliza de manera equitativa todos los recursos disponibles y para los presentes resultados, no existe una tendencia o una preferencia marcada hacia alguno de ellos, ni para alimento, ni para refugio.

La relación entre abundancia, frecuencia, dominancia y área basal es proporcional, lo que índica que todas las especies presentan un grado significativo de importancia para la estructura de los parches y por tanto cada especie es fundamental para el mantenimiento de las poblaciones de $S$. sciureus.

La desaparición o aislamiento de primates tiene grandes consecuencias ya que por su nicho trófico son dispersores importantes de semillas, modifican la composición y distribución de los bosques. Además, tienen un papel muy importante como controladores de insectos (3).

Durante el desarrollo del presente estudio se evidenciaron los procesos graves de transformación y fragmentación a los que se ha sometido a los bosques y ecosistemas de la zona. Dicho aspecto constituye un punto neurálgico y debe ser el epicentro de los esfuerzos de conservación, es decir, la permanencia y salud poblacional de las especies, no sólo de primates, sino del resto de la fauna y flora que habita en estos bosques, depende principalmente de la implementación de estrategias de restauración de la conectividad y el reestablecimiento de corredores biológicos que permitan que las redes de transferencia de energía y biomasa del sistema funcionen correctamente.

El tamaño en las tropas de Titi está relacionada positivamente con el porcentaje del componente arbóreo, oferta de frutos, áreas húmedas y la densidad de los bordes en el ecotono y negativamente con la presencia de otros primates, predadores o ausencia de insectos (3). Al preferir el hábitat secundario, la mezcla de bosques en diferentes etapas de sucesión, aumenta la vulnerabilidad de la especie por la presencia del hombre y el uso indiscriminado de agroquímicos. 
Finally, the results obtained in terms of phenological and structural dynamics in the forest fragments under study allow establishing that despite the obvious ecological problem of these forests, it is still possible to induce nature through active restoration programs for strengthening the existing dynamics and balance the biogeochemical dynamics of the ecosystem in a relatively short period of time, so that the socioeconomic human activities already established supporting the population are not contrary to the conservation efforts and vice versa.

\section{Acknowledgements}

This article is part of agreement 28205-007, Minutes 03. Cormacarena - Research institute (IIOC) of Universidad de los Llanos. The authors also thank Javier Hernandez (r.i.p.), for his fieldwork and Mauricio Torres M. for his unconditional support.
Finalmente, los resultados obtenidos en cuanto a dinámica fenológica y estructural de los fragmentos de bosque estudiados permiten establecer que a pesar del evidente problema ecológico de estos bosques, aún es posible inducir a la naturaleza a través de programas de restauración activa para fortalecer esa dinámica aún existente y equilibrar en un tiempo relativamente corto la dinámica biogeoquímica del ecosistema, de manera tal, que las actividades antrópicas socio-económicas ya establecidas, que sustentan a la población, no vayan en contraposición de la conservación y viceversa.

\section{Agradecimientos}

Este artículo hace parte del convenio 28205-007, Acta 03. Cormacarena- instituto de investigaciones (IIOC) de la Universidad de los Llanos. Los autores también agradecen a Javier Hernández (q.e.p.d.), por su trabajo en campo y a Mauricio Torres M. por su apoyo incondicional.

\section{REFERENCES}

1. Defler TR. Historia natural de los primates colombianos. 2da edición. ed. Bogotá: Universidad Nacional de Colombia. Facultad de Ciencias. Departamento de Biología; 2010.

2. IUCN. The IUCN Red List of Threatened Species: International Union for Conservation of Nature and Natural Resources; 2003. Available URL: http://www.iucnredlist.org/details/41537/0.

3. Solano D, Wong G. Hábitat y población de mono tití (Cebidae: Saimiri oerstedii oerstedii) en la península de Osa, Costa Rica. Ambientales 2009; 38:33-46.

4. Ruiz-García M, Leguizamón N, Vásquez C, Rodríguez K, Castillo MI. Métodos genéticos para la reintroducción de monos de los géneros Saguinus, Aotus y Cebus (Primates: Cebidae) decomisados en Bogotá, Colombia. Rev Biol Trop 2010; 58(3):1049-67.

5. Ruiz-García M, Castillo MI, Álvarez D, Gardeazabal J, Borrero LM, Ramírez DM, et al. Estudio de 14 especies de primates platirrinos (Cebus, Saimiri, Aotus, Saguinus, Lagothrix, Alouatta y Ateles), utilizando 10 loci microsatélites: análisis de la diversidad génica y de la detección de cuellos de botella con propósitos conservacionistas. Rev Orinoquia 2007; 11:19-37.
6. Buckland ST, Plumptre AJ, Thomas L, Rexstad EA. Design and analysis of line transect surveys for primates. Int J Primatol 2010; 31(5):833-47.

7. Leonardi $R$, Buchanan-Smith $H M$, Dufour V, MacDonald C, Whiten A. Living together: behavior and welfare in single and mixed species groups of capuchin (Cebus apella) and squirrel monkeys (Saimiri sciureus). Am J Primatol 2010;72(1):33-47.

8. IGAC. Cartographer Cobertura y uso de las Tierras. [en linea]. Colombia: IGAC; 2005. URLDisponible en: http://geoportal.igac.gov.co/ssigl2.0/visor/ galeria. req? mapaId $=9 \&$ title $=$ Cobertura $\% 20$ uso $\% 20$ de $\% 20 l a \% 20$ tierra.

9. González DU, Estrada E, Cantú-Ayala C. Análisis de fragmentación en colonias del perrito llanero mexicano (Cynomys mexicanus). Ciencia-UANL 2012; 15(57):43-9.

10. Dueser RD, Shugart Jr HH. Microhabitats in a forest-floor small mammal fauna. Ecology 1978; 59(1):89-98.

11. Gómez-Posada C. Dieta y comportamiento alimentario de un grupo de mico maicero Cebus apella de acuerdo a la variación en la oferta de frutos y artrópodos, en la Amazonía colombiana. Acta Amazónica 2012; 42(3):363-72. 
12. Williams LE, Brady AG, Abee CR. Squirrel monkeys. The UFAW Handbook on the Care and Management of Laboratory and Other Research Animals, Eighth Edition 2010: 564-78.

13. Trevino HS. Seasonality of reproduction in captive squirrel monkeys (Saimiri sciureus). Am J Primatol 2007; 69(9):1001-12.
14. Manel S, Schwartz MK, Luikart G, Taberlet P. Landscape genetics: combining landscape ecology and population genetics. Trends Ecol Evol 2003; 18(4):189-97.

15. Guisan A, Thuiller W. Predicting species distribution: offering more than simple habitat models. Ecol Lett 2005;8(9):993-1009. 